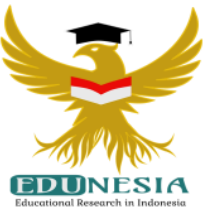

\title{
Analysis of Language Errors in the "Larise" Magazine Article at SMP Negeri 8 Surakarta
}

\author{
Dea Rahmanita Ayuningtyas; Lailatul Karimah²; Silvi Intan Cahyaningsih³; \\ Chafit Ulya ${ }^{4}$ \\ 1, 2, 3,4 Indonesian Language Education, Sebelas Maret University, Indonesia \\ ${ }^{1}$ Corresponding Email: dea.rahmanita7@student.uns.ac.id, Phone Number : 0813 xxxx xxxx
}

\author{
Article History: \\ Received: Nov 30, 2021 \\ Revised: Dec 10, 2021 \\ Accepted: Dec 15, 2021 \\ Online First: Jan 02, 2022
}

\section{Keywords:}

EBI,

Morphology,

Syntax.

\section{Kata Kunci:}

EBI,

Morfologi,

Sintaksis.

\section{How to cite:}

Ayuningtyas, D.R., Karimah, L., Cahyaningsih, S.I., \& Ulya. C. (2022). Analysis of Language Errors in the "Larise" Magazine Article at SMP Negeri 8 Surakarta. Edunesia: Jurnal Ilmiah Pendidikan, 3 (1): 55-65.

This is an open access article under the $C C-B Y-N C-N D$ license

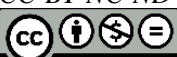

\begin{abstract}
This study aims to analyze language errors and their interpretations at the level of syntax, morphology, and Indonesian Spelling System as well as to increase knowledge and insight about how to write properly and correctly according to the language rules that have been regulated in the KBBI and PUEBI. This research uses descriptive qualitative research method. The data in this study are in the form of words (not numbers) sourced from Larise magazine in an article entitled "Philosophy of Kidungan Jawa "Ana Kidung Rumeksa ing Wengi" published on Sunday, October 11, 2020. The data collection technique in this study is a note-taking technique, namely: by reading Larise magazine as a data source. The analysis used in this study is an interactive analysis which includes the steps of a) data collection, b) error identification, c) error explanation, d) error classification, and e) error evaluation. In this study, an analysis of errors in writing rules was carried out at the level of syntax, morphology, and accuracy in the use of Indonesian Spelling (EBI). Errors at the syntactic level are in the form of errors in the use of effective sentences, errors at the morphological level are affixation errors, and errors related to Indonesian spelling include errors in using punctuation marks, using capital letters, using standard words, using prepositions, and using particles.
\end{abstract}

Abstrak: Penelitian ini bertujuan untuk menganalisis kesalahan berbahasa dan pembetulannya pada tataran sintaksis, morfologi, dan Ejaan Bahasa Indonesia (EBI) serta untuk menambah pengetahuan dan wawasan terkait cara menulis yang baik dan benar sesuai kaidah kebahasaan yang telah diatur pada Kamus Besar Bahasa Indonesia (KBBI) dan Pedoman Umum Ejaan Bahasa Indonesia (PUEBI). Penelitian ini menggunakan metode penelitian deskriptif kualitatif. Data dalam penelitian ini berupa kata-kata (bukan angka) yang bersumber dari majalah Larise pada artikel berjudul "Filsafat Jawa Kidungan "Ana Kidung Rumeksa ing Wengi" yang terbit pada Minggu, 11 Oktober 2020. Teknik pengumpulan data dalam penelitian ini adalah teknik catat, yaitu dengan membaca majalah Larise sebagai sumber data. Analisis yang dipakai dalam penelitian ini adalah analisis interaktif yang meliputi langkah-langkah a) pengumpulan data, b) pegidentifikasian kesalahan, c) penjelasan kesalahan, d) pengklasifikasian kesalahan, dan e) pengevaluasian kesalahan. Pada penelitian ini dilakukan analisis kesalahan kaidah penulisan pada tataran sintaksis, morfologi, dan ketepatan penggunaan Ejaan Bahasa Indonesia (EBI). Kesalahan pada tataran sisntaksis yaitu berupa kesalahan dalam penggunaan kalimat efektif, kesalahan dalam tataran morfologi adalah pada kesalahan afiksasi, dan kesalahan terkait Ejaan Bahasa Indonesia meliputi kesalahan penggunaan tanda baca, penggunaan huruf kapital, penggunaan kata baku, penggunaan kata depan, dan penggunaan partikel. 


\section{A. Introduction}

Indonesian is the official language of the Unitary State of the Republic of Indonesia as stated in the 1945 Constitution of the Republic of Indonesia, article 36. Indonesian also acts as the language of the Indonesian nation's unity which is implied in the Youth Oath of October 28, 1928. Indonesian is also widely used as the mother tongue in everyday conversations of the people. In addition, language is also a tool and an important aspect in communicating and conveying information. According to Apriani (2016) language is a reflection of the human mind and language cannot exist without human thought and vice versa. In addition, language is defined as a means of communication, either directly or indirectly. According to Wijayanti (2014) language has a function as a communication tool, one of which is to give birth to a thought and feeling that allows the person to be able to work together with others. So, language is a communication tool that comes from the human mind in order to give birth to ideas or ideas that can be understood by other people as observers. In this concept. Wiratno \& Santosa (2011) explained that language is understood in terms of expression and potential meaning. In the community environment definitely need the media to help smooth when communicating and obtaining information from the outside world. (Cangara , 2010) defines media as a tool or means used to convey messages from communicators to audiences, while the notion of mass media itself is a tool used in delivering messages from sources to audiences by using communication tools such as newspapers, films. , radio and television. From the many examples of mass media that we know, the author chooses magazines as one of the media that can be used as a source to get information.

In relation to the function of a magazine as a medium for disseminating information, Adji (2008) defines a magazine as a communication tool that is general in nature and published regularly, which functions as a disseminator of information and a means of struggle to achieve development goals. (Baran, 2012; Cangara, 2010; Kurniawan, 1995) states the notion of a magazine is a periodical publication (not daily) that is published regularly and the nature of its content does not display news or news extracts, but in the form of articles, or articles. which is a comprehensive and in-depth discussion. The magazine in it also contains various journalistic coverage results. Not only that, magazines are also often used to publish a written work which includes various information that is currently being discussed. (Baran, 2012) in his book "Introduction to Mass Communication, Media Literacy and Culture" divides the types of magazines based on their market, namely mass magazines (general magazines), class magazines (magazines aimed at certain groups), and specialized magazines (magazines aimed at specifically to readers by raising certain topics). Magazines or commonly referred to as magazine articles can also be used to convey an idea from the author to the public. In addition, the magazine articles are able to have an impact in academic terms for writers and can help writers understand the purpose of writing and also help writers to be able to think critically and systematically in training to use good and correct written language according to the rules. In this modern era, magazines are not only in print but can be accessed online on the internet. According to Sinulaki (2013), the 
magazine is one of the media of communication and information in detail because it is different from other mass media. The characteristics possessed by the magazine can be seen from the way the author conveys an implied message on the content of the topic that the author writes. In magazine writing, it is not only writing long and meaningful words to attract readers' interest. However, the author must pay attention to the use of spelling and linguistic rules in accordance with the rules of the Big Indonesian Language Dictionary (KBBI) and the General Guidelines for Indonesian Spelling (PUEBI). This is very important because the way of writing in magazine articles greatly affects the level of understanding of the reader in understanding the information contained in it. The purpose of writing articles in accordance with the KBBI and PUEBI is so that the content can be easily understood and accepted by readers. Therefore, magazine writers must be more careful in writing their writings and can avoid mistakes in linguistic rules so that the information conveyed is not ambiguous and ends up being difficult for readers to understand. In addition, there needs to be enthusiasm from the reader because it is to make it easier for the author of the article to convey information from the results of his writing so that it is easy for readers to understand and understand.

In relation to language errors, this paper can be used as a source of learning Indonesian. Learning is a process in helping students or students to be able to learn well. According to (Abidin, 2015) learning is a series of processes carried out by teachers so that students learn. Through learning Indonesian, educators must be able to explain the theory that raises a language error material. It has a goal that is in line with learning, namely learning Indonesian language that is able to direct students' ability to communicate, both orally and in writing. However, it is very unfortunate that some Indonesian people think that Indonesian can only be used as a means of communication. The thoughts of most people say that if you can or are able to use Indonesian and the other person or reader understands it then you feel good and right. It is not that easy to say or write in Indonesian which is able to make other people understand what the writer or speaker wants. This requires the ability to understand the ins and outs of good and correct linguistic rules. Good language is used with an emphasis on the communicative aspect of language, while the correct language is related to the rule aspect, namely language rules. There are four language rules that must be considered, namely problems in grammar, word choice, punctuation, and spelling. It is also known that good and correct Indonesian is identical to the standard language. According to Idrus (2021) standard Indonesian is the language used by the community with the widest coverage and the greatest authority rather than using non-standard language.

This can be in line with the development of science and technology. People are required to have good and correct language skills. Not only mastering foreign languages, but also being able to speak Indonesian properly and correctly. It is useful for the community in terms of conveying information both orally and in writing. In harmony with language skills which have four aspects, namely listening skills, speaking skills, reading skills, and writing skills (Tarigan, 2013). Thus, Indonesian language learning can be taught not only focused on theory but also on the practice of using Indonesian properly and 
correctly according to linguistic rules. In the practice of learning, students can be given signs in advance regarding errors in language both spoken and written so that students understand and understand. The next step, students are given training to make a scientific essay or make an article with a predetermined theme. Students are free to explore and find relevant sources by using the internet to support their writing. In addition, students are given directions to analyze language errors in the articles that have been prepared. For example, educators provide magazine articles that must be analyzed in the study of language errors, students are given signs to analyze in terms of syntactic, semantic, phonological, morphology, and Indonesian Spelling (EBI) errors in magazine articles that have been prepared by the teacher. In addition, these activities are able to familiarize students with reading (literacy) and carefully looking for writing errors in an article or magazine and providing corrections.

Errors that usually occur in magazine writing, which usually occur in terms of syntax, semantics, morphology, phonology, use of punctuation, spelling, capitalization, writing italics, and standard or non-standard words are included at the Indonesian Spelling level. This can be categorized as a language error. These language errors are categorized as errors in linguistic studies. According to Unsiah (2018) linguistics is a term that comes from the Latin language, namely lingua which means 'language'. The error that will be reviewed in this article is included in the study in the section on types of micro linguistics. Micro linguistics is a study of the object of linguistics which only focuses on the internal structure of language. According to Nisa (2018) language errors are ways of using good and correct language orally and in writing that deviate from the Indonesian language rules. Analysis of language errors according to Maulidiah (2017) is an analysis of language errors that should pay attention to the analysis of the existing discourse as a whole so that there is no overlap of meaning. This can be included in the study of language error analysis contained in Larise magazine. It can also be used as input or advice to the author of the article regarding writing which must pay attention to good and correct linguistic rules.

Similar research was conducted by Kartini (2019) in his research entitled "Analysis of Language Errors in Toga Magazine Edition III in December 2018". In addition, there are still research results that analyze the same thing, namely research from Fernandez (2018) entitled Analysis of Language Errors in the "FOKUS" Rubric of Student Opinion Magazine, research Fitriani (2021) entitled Analysis of Spelling Language Errors in "Mulia Magazine" April 2020 edition, as well as research from Permatasari (2019) entitled Language Errors in Pandawa Magazine IAIN Surakarta 2018 Edition at the Spelling and Syntactic Level. The research conducted explains about the errors that exist in the magazine in the field of linguistics. The language errors in the study were stated to consist of language errors at the level of syntax, semantics, morphology, phonology, and EBI. The meaning of these errors when translated means as follows: first, language errors at the syntactic level are errors in the field of relationships between words and sentences. Second, errors at the semantic level are language errors in the study of language meaning. Third, morphological errors are language errors that are often encountered because of the lack of thoroughness of the article writer 
regarding words and word formation. Fourth, phonological errors in the analysis of language errors can be found related to the problem of language sounds with their relation as differentiators of meaning. Finally, errors in the Indonesian Spelling study, which are often found related to spelling problems, the use of capital letters, italics, punctuation marks, and others. The author took Larise Magazine as the object of research because it was analyzed.

\section{B. Method}

This research uses descriptive qualitative research method. Inderasari \& Agustina (2017) stated that descriptive qualitative research aims to describe systematically, factually, and accurately about the facts, characteristics, and relationships between phenomena that have been provided. The data in this research came from an Indonesian error in LariseMagazine in an article entitled "Philosophy of Kidungan Java "There are Kidung Guarding at Night" which was published on Sunday, October 11, 2020. The procedure for collecting data in this research was to read and find words and phrases sentence from article "Philosophy of Kidungan Java "There are Kidung Guarding at Night" that published in LariseMagazine. The data collection technique in this research was a note-taking technique. In addition, this research is included in the type of qualitative research so the data obtained are in the form of words (not numbers) and analyzed using qualitative analysis methods. This research uses a written technique. The analysis used in this study is an interactive analysis which includes the steps of a) data collection, b) error identification, c) error explanation, d) error classification, and e) error evaluation.

\section{Results and Discussion}

In this study, an analysis of errors in writing rules was carried out at the level of syntax, morphology, and accuracy in the use of Indonesian Spelling (EBI). The research sample used was an article entitled "Filsafat Jawa Kidungan "Ana Kidung Rumeksa Ing Wengi" which was published in magazine Larise which was published on Sunday, October 11, 2020. The following is the result of classification of Indonesian language error data in Larise magazine at SMP Negeri 8 Surakarta.

\section{Syntactic Level Writing Errors}

Two writing errors at the syntactic level were found in themagazine articlemagazine article Larise entitledentitled "Ana Kidung Rumeksa Ing Wengi" Ana Kidung Rumeksa Ing Wengi" published on Sunday, October 11, 2020. The errors found are in the form of sentence structure errors contained in the following two sentences.

(1) Filsafat Jawa adalah ilmu yang mempelajari tentang filsafat yang bertumpu pada pemikiranpemikiran yang berakar pada budaya Jawa"

(2) Penulis sendiri waktu itu belum tahu artinya sama sekali." 
The sentence is less precise and less effective when viewed from the structure of the sentence so that there are some words that must be replaced or omitted to be more precise and effective. Sentence structure is a combination of syntactic functions in the form of sentence building elements consisting of subject, predicate, object, description, and complement. This will affect the sentences that are arranged to be effective or ineffective. Effective sentences are sentences that are short, dense, clear, and complete and can convey complete and precise information. So, the form of justification for the error is as follows.

(1) "Filsafat Jawa adalah ilmu filsafat yang bertumpu pada pemikiran budaya Jawa".

(2) "Penulis waktu itu belum tahu artinya sama sekali."

\section{Writing Errors at the Morphological Level}

One error was found at the morphological level in the magazine article Larise entitled Philosophy of Kidungan Java "Ana Kidung Rumeksa Ing Wengi" which was published on Sunday, October 11, 2020. The errors found were in the form of word structure errors, namely in the use of prefixes contained in the following sentences.

(3) "Dalam "Sarine Basa Jawa", Padmasukatja (1967) disebutkan "Kalabendu" sebagai jaman dimana kesusilaan manusia sudah rusak. Ada pengaruh "Bathara Kala disitu".

The word mentioned is the result of the affixation process in the form of the addition of a prefix that is not appropriate if it is included in the context of the sentence. The word mentioned can be changed to mention. The use of the prefix di- (means: in) on the word "disebutkan (means: mentioned)" is a mistake. Prefix di- in Indonesian functions as a passive verb and related to its active form uses prefix me-. In the sentence "In "Sarine Javanese Language", Padikutjatja (1967) mentions "Kalabendu" as an era ..." the subject is a animate noun or person. So, the prefix used should be me- + the root word that prefix s, then it changes to meny- "me- + sebut + kan = menyebutkan (means: mention)". So, the form of justification for the error is as follows. "Dalam "Sarine Basa Jawa", Padmasukatja (1967) menyebutkan "Kalabendu" sebagai jaman di mana kesusilaan manusia sudah rusak. Ada pengaruh "Bathara Kala di situ".

\section{Spelling Level Writing Errors}

There were 8 errors at the spelling level found in themagazine article Larise entitled Philosophy of Javanese Kidungan "Ana Kidung Rumeksa Ing Wengi" which was published on Sunday, October 11, 2020. The errors found were errors in writing prepositions, typos, use of particles, writing capital letters, writing standard words, and using punctuation marks.

a. Errors in writing prepositions

Several errors were found in the use of prepositions or prepositions in the magazine article Larise entitled Philosophy of Java Kidungan "Ana Kidung Rumeksa Ing Wengi" which was published on Sunday, October 11, 2020. The error is contained in the following sentence.

(3) "...sebagai jaman dimana kesusilaan manusia sudah rusak. Ada pengaruh "Bathara Kala disitu". 
In the above phrase the word di should have a function as a preposition, not as a prefix, so it should be written separately from the word that follows it. In the Indonesian spelling rules, prepositions, such as $d i, k e$, and dari, are written separately from the words that follow them. So, the correct word "dimana" is di mana and the correct word "disitu" is di situ. So, the correction of the sentence is "...sebagai jaman di mana kesusilaan manusia sudah rusak. Ada pengaruh "Bathara Kala di situ".

b. Word Writing Errors (Wrong Typing)

Several typos were found in the magazine article magazine article Larise entitled Philosophy of Java Kidungan "Ana Kidung Rumeksa Ing Wengi" which was published on Sunday, October 11, 2020. The error is contained in the following sentence.

(4) "...jim setan datan purun..."

There is a typo in this sentence. When adjusted to the context of the sentence which is a Javanese kidung poem, the words jim and datan are not very appropriate. In KBBI, the meaning of the word "jim" is the name of the 5th letter of the Arabic alphabet, while the word "datan" is not found in its meaning. Judging from the context of the sentence and the discourse, there was an error in writing the word jinn into jim and the word coming into datan. KBBI defines the word jim as a spirit created from fire, while the word comes means arriving at the destination, originating, being present, appearing, later, or later. Thus, the correct writing of the word is the word jin and come so that it fits the context of sentences and discourses and the meaning can be found in the KBBI. So, the correction of the sentence is "Jinn setan datang purun."

\section{c. Even Particle Writing Errors}

It was found that one particle writing error was found in the magazine article Larise entitled Philosophy of Kidungan Java "Ana Kidung Rumeksa Ing Wengi" which was published on Sunday, October 11, 2020. The error is contained in the following sentence.

(5) "Pencuripun menjauh dariku".

In this sentence there is an error in writing particles. According to PUEBI particles any a separate writtenof words medahuluinya except the particles that are a series of elements common words written, as though, evenif, while, and however.In this sentence, the particle is also preceded by the word thief which is included in a noun (noun) so that even the particles can not be written in series. Thus, the use of particles also mustbe separated from the word that precedes it, namely the word thief so that it is appropriate and in accordance with PUEBI. So, the correction of the sentence is "Pencuri pun menjauh dariku."

\section{d. Capital Lettering Errors}

It was found as many as one writing error in the use of capital letters in themagazine article Larise entitled Philosophy of Java Kidungan "Ana Kidung Rumeksa Ing Wengi" which was published on Sunday, October 11, 2020. The error is contained in the sentence following. 
(6) "Namun demikian Orang Tua selalu menjawab pertanyaan dari anak-anaknya dengan penuh kesabaran".

In the sentence there is an error in the use of capital letters. According to PUEBI, capital letters are used as the first letter of the beginning of a sentence; the first letter of the element of the person's name, including the nickname. In this sentence the use of capital letters in the word "Orang Tua" incorrect because it does not comply with the rules for using capital letters in PUEBI as stated above. Thus, the use of capital letters at the beginning of the word 'Orang Tua' must be changed to lowercase letters, namely "orang tua". So, thesentence is " Namun demikian orang tua selalu menjawab pertanyaan dari anak-anaknya dengan penuh kesabaran".

\section{e. Corrected Errors in Writing Standard Words}

There were three errors in writing standard words in the magazine article Larise entitled Philosophy of Java Kidungan "Ana Kidung Rumeksa Ing Wengi" which was published on Sunday, October 11, 2020. The errors are contained in the following sentence.

(7) "... beriman dan bertaqwa kepada Tuhan Yang Maha Esa"

In this sentence there is an error in writing the standard word. According to the KBBI the word "bertaqwa" has no meaning. The standard word of bertaqwa is pious. As stated in the KBBI, the word bertakwa has the meaning of carrying out piety. Thus, the correct use of the sentence in the news sentence is takwaa. In this sentence, the use of the word piety is not appropriate because it is not in accordance with the KBBI. So the correction of the sentence is ... beriman dan bertakwa kepada Tuhan Yang Maha Esa."

(8) “...memberikan pedoman bagi masyarakat Jawa dalam menghadapi datangnya jaman edan atau jaman kala bendhu dan kalatidha"

In this sentence there is an error in writing the standard word. According to KBBI, the word era has no meaning. The standard word for "jaman" is zaman. According to the KBBI, the word zaman means a long or short period of time that marks something. Thus, the correct use of the sentence in the news sentence is era. In this sentence, the use of the word 'age' is not appropriate because it is not in accordance with the KBBI. While the standard word for "kala bendhu" is kalabendu. As stated in the KBBI, the word kalabendu means an era filled with sad or frightening events; dark times. Thus, the correct use of the sentence in the news sentence is zaman. In this sentence, the use of the word kala bendhu is incorrect because it is not in accordance with the KBBI. So, the correction of the sentence above is ...memberikan pedoman bagi masyarakat Jawa dalam menghadapi datangnya zaman edan atau zaman kalabendu dan kalatidha".

(9) "Kidung ini biasa dinyanyikan pada malam hari, atau selepas shalat malam"

In this sentence there is an error in writing the standard word. According to the KBBI the word "salat" has no meaning. The standard word for "shalat" is salat. As stated in the KBBI, the word salat has the meaning of the second pillar of Islam, in the form of worshiping 
Allah SWT. So the correction of the sentence is "Kidung ini biasa dinyanyikan pada malam hari, atau selepas salat malam.

\section{f. Punctuation Error}

One punctuation error was found in the magazine article Larise entitled Philosophy of Java Kidungan "Ana Kidung Rumeksa Ing Wengi" which was published on Sunday, October 11 2020. The error is contained in the following sentence.

"Kidung ini biasa dinyanyikan pada malam hari, atau selepas shalat malam"

In this sentence there is an error in the use of a comma (,). According to PUEBI, a comma (,) is used between elements in an itemization or numeration; before conjunctions, such as tetapi, melainkan, and sedangkan, in a compound sentence (equivalent). In this sentence, a comma (,) is placed before the word or is not appropriate because it does not declare one of the functions of the comma (,). Thus, the use of a comma (,) in the sentence must be removed. So, the correction of the sentence is "Kidung ini biasa dinyanyikan pada malam hari atau selepas shalat malam."

\section{Conclusion}

Based on the discussion of the data above, both at the syntactic, morphological, and EBI levels, it can be concluded that the tendency of language errors in Larise magazine is mostly found at the EBI level. In the data classification at the syntactic level, there are 2 errors in the use of effective sentences. At the morphological level there is 1 error. Error analysis at the morphological level in this study is the affixation error, namely the use of the prefix di-. Errors found related to Indonesian Spelling such as errors in using punctuation marks, using capital letters, using standard words, using prepositions, and using particles. So, the total language errors that have been analyzed in Larise magazine are 11 errors. Future research is expected to be able to analyze and examine language errors more deeply than this research.

\section{Acknowledgment}

This research can be carried out well thanks to various parties who have helped. Therefore, the authors would like to thank all staff and employees of Larise magazine at SMP Negeri 8 Surakarta who have published Larise magazine which is used as the source of this research. Thanks also to the entire Edunesia Journal team for being willing to review this article.

\section{References}

Apriani, M. (2016). Analisis Kesalahan Berbahasa Bidang Morfologi oleh Komunitas Jual-Beli Online di Mataram Nusa Tenggara Barat. Mataram: Skripsi. Program Studi Pendidikan Bahasa, Sastra Indonesia dan Daerah. Universitas Mataram. http://eprints.unram.ac.id/id/eprint/3124 
Abidin, Y. (2015). Pembelajaran multiliterasi: sebuah jawaban atas tantangan pendidikan abad ke21 dalam konteks keindonesiaan. Bandung: Refika Aditama.

Baran, S. J. (2012). Pengantar Komunikasi Melek Media dan Budaya. Jakarta: Erlangga.

Cangara, H. (2010). Pengantar Ilmu Komunikasi. Jakarta: PT. Raja Grafindo Persada.

Fernandez, Y. D. (2018). Analisis Kesalahan Berbahasa Dalam Rubrik "FOKUS" Majalah Pendapat Mahasiswa. Caraka, 4(2), 34-51. https://doi.org/10.30738/caraka.v4i2.2844

Fitriani, A. M. (2021). Analisis Kesalahan Berbahasa Tataran Ejaan pada Majalah "Mulia" Edisi April 2020. Jurnal Genre, 3(1), 1-9. https://doi.org/10.26555/ig.v3i1.3391

Hamzah, A. (2008). Delik-Delik Pers Indonesia. Jakarta: Media Sarana.

Inderasari, E., \& Agustina, T. (2017). Pembelajaran Bahasa Indonesia pada Mahasiswa Asing dalam Program BIPA IAIN Surakarta. Jurnal Pendidikan Bahasa dan Sastra Indonesia, 6 (2). https://doi.org/10.15294/jpbsi.v6i2.20192

Idrus, S. (2021). Analisis Kesalahan Berbahasa Dalam Interaksi Pembelajaran Bahasa Indonesia Siswa Kelas VII Madrasah Tsanawiyah Alkhairaat Pinotu. Guru Tua, 19-24. https://doi.org/10.31970/gurutua.v4i1.62

Kurniawan, J. (1995). Rahasia Dapur Majalah di Indonesia. Jakarta: PT. Gramedia Pustaka Utama.

Kartini;, K. R. (2019). Analisis Kesalahan Berbahasa Pada Majalah Toga Edisi III Bulan Desember Tahun 2018. IMAJERI, 02, No. 1, 11-23. https://doi.org/10.22236/imajeri.v2i1.5073

Maulidiah, R. H. (2017). Problematika Menganalisis Wacana Secara Tekstual Dan Kontekstual Mahasiswa Fkip Una. Bindo Sastra, 1(2), 95-102. DOI: $\underline{\text { https://doi.org/10.32502/jbs.v1i2.750 }}$

Nisa, K. (2018). Analisis Kesalahan Berbahasa Pada Berita Dalam Media Surat Kabar Sinar Indonesia Baru. Bindo Sastra, 218-224. DOI: https://doi.org/10.32502/jbs.v2i2.1261

Mahsun. (2005). Metode Penelitian Bahasa. Yogyakarta: Duta Wacana University Press.

Maulida, U. (2021, Februari). Kesalahan Berbahasa Tataran Ejaan, Morfologi, Dan Sintaksis Skripsi Mahasiswa Program Studi Pgmi Binamadani. Dirasah, 4, 24-34. DOI: https:// doi.org/10.51476/dirasah.v4i1.220

Permatasari, N. E. (2019). Kesalahan Berbahasa dalam Majalah Pandawa IAIN Surakarta Edisi 2018 pada Tataran Ejaan dan Sintaksis. Diglosia: Jurnal Kajian Bahasa, Sastra, dan Pengajarannya, 2(2), 103-114. https://doi.org/10.30872/diglosia.v2i2.22 
Parera, J. D. (2007). Morfologi Bahasa. Jakarta: Gramedia Pustaka Utama.

Sinulaki, A. (2013). Jenis-Jenis Komunikasi Massa. Dipetik November 18, 2021, dari goresankuliahku: http://goresankuliahku.blogspot.com/2013/05/jenis-komunikasimassa-majalah.html.

Tarigan, H. G. (2013). Menulis sebagai Keterampilan Berbahasa. Bandung: Angkasa.

Unsiah, F. \& Yuliati, R. (2018). Pengantar Ilmu Linguistik. Malang: UB Press.

Wiratno, T., \& Santosa, R. (2011). Pengantar Linguistik Umum. Jakarta: Universitas Terbuka.

Wijayanti, D. R. (2014). Analisis Kesalahan Berbahasa Bidang Morfologi pada Karangan Narasi Siswa Kelas VII Madrasah Tsanawiyah Muhammadiyah 1 Weleri Tahun Ajaran 2013/2014. Surakarta: Skripsi. Pendidikan Bahasa dan Sastra Indonesia. Universitas Muhammadiyah Surakarta. http://eprints.ums.ac.id/id/eprint/31072 